the Royal College of Science and Technology. Of interest to schoolchildren and their parents will be an exhibition, "Science in Schools", arranged by the local officers of the Science Masters' Association.

A novel feature of the 1958 meeting will be a series of lecture-demonstrations for school-children given by eminent scientists. The publicity given to this innovation, coinciding as it did with a local schoolchildren's exhibition and the British Association's own recent conference on "Science in Schools", may have created the impression locally that the Association's interests are turning exclusively to the advancement of science among school-children. There is no doubt, however, that it has given a welcome fillip to the publicity campaign undertaken by the Local Committee on the Association's behalf, and that the progress of the 'Junior British Association', as it has come to be known, will be followed with much interest.
The Local Committee has not neglected the lighter side. A dinner or similar function is planned for each section of the Association, while a large-scale reception for the members will be given by the Corporation in the City Chambers and in the Art Gallery and Museum, Kelvingrove. Other social functions will include a reception arranged by the British Council for overseas guests, and a reception promoted by the scientific societies of Glasgow and district for visitors sharing their interests. On the evening of Sunday, August 31, a symphony concert will be given by the B.B.C. Scottish Orchestra in St. Andrew's Hall.

The Association meets in Glasgow under the presidency of Sir Alexander Fleck, chairman of Imperial Chemical Industries, Ltd., and himself a distinguished graduate of the University. He will address the inaugural meeting of the Association in St. Andrew's Hall on August 27 on "Science and Business : a Balanced Partnership".

\title{
OBITUARIES
}

\section{Prof. Charles F. Brooks}

The world of meteorology suffered a grievous loss in the death of Charles Franklin Brooks on January 8. Prof. Brooks will be remembered for his long tenure as director of the Blue Hill Meteorological Observatory of Harvard University and for his many contributions to climatology, synoptic meteorology and methods of observation. His services with several commissions of the World Meteorological Organiza. tion and its predecessor, the International Meteorological Organization, made him a rather frequent visitor to Great Britain and the Continent. Most recently he served on the committee that produced the new International Cloud Atlas.

Prof. Brooks was born on May 2, 1891, in St. Paul, Minnesota. He was educated at Harvard University, which awarded him the A:B. in 1911, the A.M. in 1912 and the Ph.D. in climatology in 1914. While still a student at Harvard he served as an assistant at Blue Hill, thus becoming familiar with the Observatory where he was later to spend much of his professional career. After four years in the U.S. Department of Agriculture and as an instructor in geography at Yale University, Prof. Brooks began his meteorological career in the U.S. Weather Bureau, where for two years he was editor of the Monthly Weather Review. In 1921, he was appointed associate professor (later professor) of meteorology and climatology at Clark University, Worcester, Massachusetts. In 1931, he assumed the post of professor of meteorology and director of the Blue Hill Meteorological Observatory at Harvard. He remained at Blue Hill until his retirement $a$ few months before his death.

Prof. Brooks played a leading part in the establishment of the American Meteorological Society in 1919. He served the Society with untiring devotion as its secretary from its inception until 1954, editor of its Bulletin for seventeen years and as treasurer in 1922. Through the lean years of the 'twenties and the early 'thirties Prof. Brooks almost single-handedly kept the Society alive. Fortunately, he lived to see the Society become the largest and most active meteorological society in the world. He was a member of many other societies, including the Royal Meteorological Society, and served as president of the Association of American Geographers in 1947.
Those of us who knew Prof. Brooks will remember him most for his warmth, kindness and humanity. Throughout his life he gave freely of his time and resources to the many who sought his assistance. Many American meteorologists were guided and assisted early in their careers by him. His charitable acts extended far beyond the realms of meteorology, and there is little doubt that his concern for his fellow-men acted as a detriment to his own soientific activities.

Prof. Brooks was one of our most effective spokesmen to the general public. He ably presented the case for meteorology and meteorologists through radio broadcasts, the Press, many talks and his book, "Why the Weather". He also kept his representatives in the United States Congress informed on pending legislation that involved meteorological questions. He was a staunch and effective supporter of the United States Weather Bureau.

We will sorely miss our friendly colleague in the years to $\operatorname{com} \theta$, but his influence will continue through his many good works and the example he set for his legion of friends. HENRY G. HOUGHTON

\section{Mr. Arthur Earland}

Mr. Arthur Eariand died on March 27 at Broughty Ferry, Dundee, at the age of ninety-one. Internationally known in the field of marine zoology, in particular for his contributions to our knowledge of the Foraminifera, he was by profession a Civil servant and employed in the Post Office Savings Bank Department. By all standards he was successful in both his professional and amateur ventures, and his name is a worthy addition to any list of eminent amateur naturalists of the past.

$\mathrm{He}$ was born at Lewisham on November 3, 1866, and received his only formal education at a local school. He declined a university education, feeling this would lead him to school-teaching as a career, and entered the Civil Service in 1885 as a 'boy clerk'. Here he stayed in various capacities until 1926, when ill-health caused his premature retirement. He had then been three years as an assistant controller, and during his service he was the person chiefly responsible for drafting the Stork Register Regulations, as well 